TITLE:

\title{
Japan-Egypt Hydro Network: Science and Technology Collaborative Research for Flash Flood Management
}

\section{$\operatorname{AUTHOR(S):~}$}

Sumi, Tetsuya; Saber, Mohamed; Kantoush, Sameh Ahmad

\section{CITATION:}

Sumi, Tetsuya ... [et al]. Japan-Egypt Hydro Network: Science and Technology

Collaborative Research for Flash Flood Management. Journal of Disaster Research 2013, 8(1): 28-36

\section{ISSUE DATE:}

2013-02

URL:

http://hdl.handle.net/2433/172242

\section{RIGHT:}

(C) 2013 Fuji Technology Press Co, . Ltd.; This is not the published version. Please cite only the published version.; この論文は出版社版で ありません。引用の際には出版社版をご確認ご利用ください。 


\title{
Japan-Egypt Hydro Network: Modern Methodologies for Integrated Water Resources Management in Egypt
}

\author{
T. Sumi ${ }^{1)}$, M. Saber ${ }^{2)}$, S.A. Kantoush ${ }^{3)}$, \\ ${ }^{1)}$ Disaster Prevention Research Institute, Kyoto University, Gokasho, Uji-Shi, 611-0011, JAPAN \\ ${ }^{2)}$ Geology Department, Faculty of Science, Assiut University, Assiut, 71516, Egypt \\ ${ }^{3)}$ Civil Engineering Department, Faculty of Engineering and Material Science, The German University in Cairo - GUC, New Cairo City, Main \\ Entrance of Al-Tagamoa Al-Khames, Cairo - Egypt
}

sumi.tetsuya.2s@kyoto-u.ac.jp, msaber_75@yahoo.com ; sameh.kantoush@guc.edu.eg

\begin{abstract}
The gap between education, research and practice in the hydraulics and hydrology field is recognized by many. Bridging the gap can be achieved by involving the practitioners in education and training and more particularly in the life-long learning processes. The present paper outlines the development of a shared hydraulic and hydrology-based network that seeks to bridge the gap between research, education and practice.

Hydro-Engineering projects are becoming more and more complex projects and have to be carried out in close cooperation by several experts from different disciplines and locations. This network base was developed from the contextualized problems facing the Nile delta, Nile River system, and coastal managements in Egypt. Under the umbrella of GCOE-ARS project at Kyoto University, a joint project for research and education was established between Kyoto University and three institutional research units in Egypt. Disaster Prevention Research Institute (DPRI), Kyoto University expert groups looked at problems of Nile Delta of Egypt related to their expertise and initiated Japan Egypt-Hydro Network (JE-HydroNet).
\end{abstract}

In view of the challenges that Egypt is facing in the water resources and environmental issues, the project will help to mitigate the problems and its consequences. The JE-HydroNet was formed with the aim of bringing together the leading researchers from various disciplines and institutional units that are active in the area of water resources in Egypt, together with people from industry who are responsible for practical implementations from Japanese companies. The network helps us better understand problems facing Nile River System and Delta of Egypt and how these various groups of researcher connect to one another and how, together, they can contribute to the design and implementation of better improvement of flexibility, availability, sustainability and environmental impacts of water resources in Nile Delta by developing advanced methodology for operation, monitoring, planning and management of the water resources problem. This initiative represents an exciting opportunity to create an inclusive and dynamic research group of interest bridging the gap between guidance research and practice. It will enable us to examine the ways in which learning about guidance is created and shared (beliefs, concepts, ideas, theories, actions) as well as providing a potentially powerful engine to assist with the search for new understandings of effective guidance to benefit all groups. As an application of this project, an integration of using remote sensing data and the distributed Hydrological model of Hydro-BEAM has been proposed for flash flood simulation at Wadi -El-Arish, Egypt. The simulation has been carried out to the flash flood event of Jan. 2010. The simulated results present remarkable characteristics such as short time to maximum peak, short flow duration, big damage resulting in a difficulty to evacuate the people from the prone regions.

Keywords: Joint project in science and technology, Nile River Basin, Delta of Egypt, Japan Egypt Hydro Network (JE-HydroNet), bridging research and practice, Flash flood management,

\section{INTRODUCTION}

Under the umbrella of Global Center Of Excellence Adaptation and Resilience in a Sustainable/Survivable Society to extreme weather and water conditions (GCOE-ARS) project at Kyoto University, a joint project for research and education was established between Kyoto University and three institutional research units in Egypt (Assiut and Alexandria 
Universities, and National Water Research Center (NWRC), Ministry of Water Resources and Irrigation (MWRI)).

A group of four researchers of Kyoto University made a preparatory field survey and meetings for establish of cooperative research project among institutes in JE-HydroNet, between 23rd to 30th of March 2010, in Aswan, Assiut, Alexandria, Rosetta, and Cairo in Egypt. Japan Egypt-Hydro Network (JE-HydroNet) was initiated after the visit of DPRI research group to Egypt. On 26 October 2010 the first mini-symposium was organized at Uji campus, Kyoto University, Japan. The first symposium have served the exchange of information about the latest state of research of water resources problems facing the Nile River and Nile Delta and encouraged the discussion about joint research project activities and how to combine with consulting practitioners.

This network is first of all unique in the sense that groups of international experts from a priori very distant scientific fields (hydraulics, Hydrology, flash flood and hazard map, dam operation, coastal management, sediment management in reservoirs, numerical and experimental modelling) initiated the JE-HydroNet, as well as the strong extensive knowledge and decision making responsibility of NWRC, Ministry of Water Resources and Irrigation (MWRI). Therefore, there is a need to set up an innovative system for early warning of flash-floods in the pilot area of one of Egyptian Wadis; for instance at Wadi El-Arish in Sinai Peninsula.

\section{CASE StUdy OF APPLiCATION}

The main obstacle to study flash flood is clearly the lack of reliable observations in most of the flash flood prone basins, thus, there is urgent necessity to develop a new methodology to simulate and forecast flash flood in arid regions. Wadi Elarish (Fig. 1) in Sinai Pensinula, Egypt has been selected as case study to simulate flash floods. with taking in our consideration the distribution behaviors of flash floods, assessing and evaluating of contributed water flow of wadi basins during the flash flood events to be utilized as a significant water resource, and proposing mitigation strategies to reduce the threaten effect of flash floods.

\subsection{METHODOLOGY}

A physical-based distributed hydrological model and remote sensing data as well as GIS technique have been integrated to simulate flash floods in arid regions. Hydro-BEAM (Hydrological River Basin Environmental Assessment Model) which was first developed by Kojiri, et al. ${ }^{11}$, and it was also adopted as Hydro-BEAM-WaS (Hydrological River Basin Environmental Assessment Model Incorporating Wadi
System) by Saber et al. ${ }^{12}$ and Saber ${ }^{13}$ to be applicable at wadi system in arid regions.

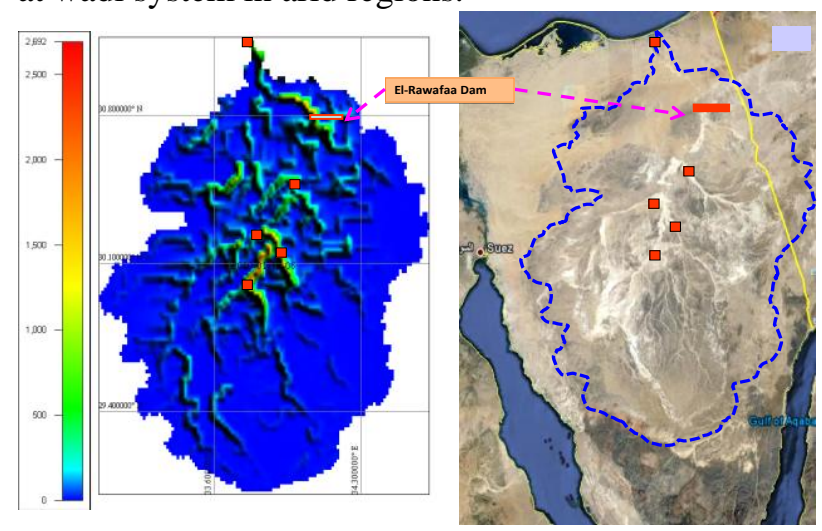

Fig. 1 Location map of Wadi El-Arish, Sinai Peninsula, Egypt, and distribution maps of discharge of Jan. 2010 flash flood event at Wadi El-Arish, Sinai Peninsula, Egypt, showing discontinuous flow of discharge (red marks are the position of sub-catchments outlets of simulation) .

\section{CONCLUSION}

This paper has tried to weave together ideas drawn from research, education and from practice in supporting the development of international hydro network. Among several proposed topics a case study of flash flood management is presented. We need more focused research approach on collaboration and measurement development in areas of interest that are underpinned by complex relations to a variety of work-related practices. We need much more data and field measurement stations for validation and accurate simulations. The JE-HydroNet was formed with the aim of bringing together the leading researchers from various disciplines and institutional units that are active in the area of water resources in Egypt, together with people from industry who are responsible for practical implementations from Japanese companies. An integration of using remote sensing data and the distributed Hydrological model of Hydro-BEAM has been proposed for flash flood simulation at Wadi-El-Arish, Egypt. The simulation has been carried out to the flash flood event of Jan. 2010.

\section{REFERENCES}

[1] Kojiri, T., Tokai, A. and Kinai, Y. (1998): Assessment of river basin environment through simulation with water quality and quantity. Annuals of DPRI, Kyoto Univ., Vol. 41, pp. 119-134, (in Japanese).

[2] Saber, M., Hamagutchi, T., Kojiri, T., and Tanaka, K. (2010): Hydrological modeling of distributed runoff throughout comparative study between some Arabian wadi basins. Annual J. of Hydraulic Eng., JSCE, Vol.54, pp. 85-90.

[3] Saber, M. (2010): Hydrological approaches of Wadi system considering flash floods in arid regions. Ph.D. thesis, Kyoto University. 